\title{
Male-killing and aposematic polymorphism in African butterflies: Is there a connection?
}

\author{
Ian Gordon \\ Ian Gordon (igordonicipe@gmail.com), BirdLife International, Africa Partnership Secretariat, PO Box 3502- \\ 00100, Nairobi, Kenya
}

Idris and Hassan (2013) look at three species of African butterflies and tackle two questions of general interest to students of evolutionary biology: 1) How can we explain the paradox of colour pattern polymorphism in co-mimetic aposematic insects, when monomorphism is predicted by classical mimicry theory, and 2) What are the evolutionary dynamics behind the spread and persistence of endosymbiotic male killers? Building on evidence for a biogeographical correlation between colour pattern polymorphism and male killers in one of the target species, Idris and Hassan propose a verbal meta-population model that links both and suggests how the latter could help to resolve the anomalies presented by the former. As the authors point out in their review of earlier work on sex ratios and Mullerian mimicry in the three species, numerous hypotheses have been suggested to resolve the questions posed, but none of them is entirely satisfactory (including my own). It is in this context that the ambitious model they propose is a useful contribution to our understanding.

In essence, Idris and Hassan suggest that male killers are responsible for a recurring series of bottlenecks, local extinctions, and founder effects, with stochastic genetic drift leading to changes in the frequencies of the colour pattern genes that sustain the polymorphism. This occurs despite overall selective pressure for Mullerian mimicry and a uniform appearance.

This is an interesting idea that I feel could apply to one of the three species (Acraea encedon) but not to the other two (A. encedana and Danaus chrysippus). The following are the relevant facts and implications for the authors' hypothesis:

1) The two Acraeas differ fundamentally in their mimicry of chrysippus: encedana is a convincing mimic throughout its range, the biogeography of its morphs matching those of chrysippus from west, through east and down to southern Africa; encedon is more often than not an unconvincing mimic, and where it is so (Tanzania; Owen and Smith 1991), encedana is absent. Furthermore, encedon populations are frequently dominated by universally nonmimetic forms, especially lycia which is common nearly everywhere and occasionally (e.g. in Gambia), the only morph. The challenge posed by aposematic polymorphism is therefore severe in encedon, but much less so in encedana.

2) The three species have very different levels of abundance and dispersion patterns: D. chrysippus is extremely common (it has in fact been dubbed "the commonest butterfly in the world", Poulton 1908), and is a highly dispersive and migratory species in which morph ratios are dynamic on a seasonal basis (because each morph has individual migration behaviour), whereas the two Acraeas are much less abundant and form tight colonies around their very different host plants. This makes local extinctions of the kind proposed somewhat improbable for the former species. The difference in dispersal pattern also vitiates the assumption that "colour pattern frequencies are spatially heterogeneous in $D$. chrysippus, A. encedon and A. encedana" (Idris and Hassan 2013: 9): this may apply from small patch to small patch in the latter two species, but only operates over vast distances in the case of chrysippus.

3) Allied to the last point, there are strong differences in dispersal behaviour between the sexes in the Acraeas. Migration is carried out almost entirely by females (Gordon 1984), which pass through habitats in which chrysippus is common but Acraeas are rare. 
Female recolonisers of habitats that have been driven to extinction by male killers are therefore likely to be exposed to Mullerian selection for chrysippus colour patterns. This should lead to colour pattern monomorphism in both Acraea species where chrysippus is itself monomorphic. While this result is observed in A. encedana (e.g. in West Africa), it does not hold for A. encedon, illustrating the complexity of the situation and the strong possibility that factors other than predator selection for mimicry are at work. A further implication of the difference in sexual dispersion behaviour is that heavily infected populations will produce higher proportions of recolonisers: but that infected females are likely to be less successful in founding new colonies in the absence of resident males since they are incapable of parthenogenesis.

4) Another crucial difference is that all-female brooding in chrysippus is subject to suppression (Smith 2013), whereas in the Acraeas no evidence for suppression has ever been found. Suppression in chrysippus is linked with one of the four subspecies, each of which shows very different incidences of allfemale broods in Tanzania and Kenya. This reinforces the implausibility of local population extinctions in this species that are driven by male killing. Suppression could also explain the breakdown of the association between male killing and colour pattern polymorphism reported by the authors in Uganda, which they cite as evidence against a hybrid hypothesis for the origin and maintenance of the polymorphism in D. chrysippus.

5) Although the hypothesis that male killers drive local extinctions in the two Acraeas is entirely reasonable, especially given the extreme scarcity of males in some of the Kampala populations of A. encedon (Owen and Chanter 1969, Owen et al. 1994), such extinction has never been observed. Indeed, such populations appear to have persisted over decades and there is evidence from Ghana that male killers remain at stable levels in natural populations (Gordon 1982).

These observations lead to the conclusion that a metapopulation and bottleneck-extinction-recolonisation hypothesis may be appropriate for A. encedon, where non-mimetic forms persist and there is heterogeneity in colour pattern frequencies between colonies, but it is unlikely to explain the situation in D. chrysippus and $A$. encedana. Paradoxes remain but Idris and Hassan introduce a novel idea into the mix which merits more consideration and research.

\section{References}

Gordon, I.J. 1982. Biology of Danaus chrysippus L. (Lepidoptera, Danaidae) and its mimics in Ghana. Ph. D thesis. University of Ghana.

Gordon, I.J. 1984. Mimicry, migration and speciation in Acraea encedon and A. encedana. Pages 193-196 in Vane-Wright, R., and P.R. Ackery, editors. The Biology of Butterflies, Vol. 11. Academic Press, London.

Idris, E. and S.S.M. Hassan. 2013. Biased sex ratios and aposematic polymorphism in African butterflies: A hypothesis. Ideas in Ecology and Evolution 6: 5-16. CrossRef

Owen, D.F. and D.O. Chanter. 1969. Population biology of tropical African butterflies. Sex ratio and genetic variation in Acraea encedon. Journal of Zoology 157: 345-374. CrossRef

Owen D.F., and D.A.S. Smith. 1991. All-female broods and mimetic polymorphism in Acraea encedon (L.) (Lepidoptera: Acraeidae) in Tanzania. African Journal of Ecology 29: 241-247. CrossRef

Owen, D.F., Smith, D.A.S., Gordon, I.J. and A.M. Owiny. 1994. Polymorphic Müllerian mimicry in a group of African butterflies: a reassessment of the relationship between Danaus chrysippus, Acraea encedon and Acraea encedana (Lepidoptera: Nymphalidae). Journal of Zoology 232: 93-108. CrossRef

Poulton, E.B. 1908. Essays on Evolution. Oxford: Clarendon Press.

Smith, D.A.S. 2013. African Queens and their Kin: A Neo-Darwinian Odyssey. Harpenden, UK: Brambleby Books Ltd. 